\title{
Intensive livestock systems based on local resources in Vietnam: use of sugar cane by-products in diets for simple-stomached animals
}

\author{
R. B. Ogle ${ }^{1}$ and T. R. Preston ${ }^{2}$ \\ ${ }^{1}$ Department of Animal Nutrition and Management, Swedish University of Agricultural Sciences, Box 7024, \\ 75007 Uppsala, Sweden \\ ${ }^{2}$ Convenio Interinstitucional para la Producción Pecuaria en el Valle del Rio Cauca, Apartado Aćreo 7482, Cali, Colombia
}

\section{Introduction}

Sugar cane is the second most important crop in Vietnam, with around 140000 ha producing $5.2 \times 10^{6} \mathrm{t}$ of cane in 1990. Most of this is processed on an industrial scale, with ' $\mathrm{C}$ ' molasses as the principal byproduct, but small-scale artisan methods for extracting sucrose are still widely used, giving rise to enriched ' $A$ ' molasses. This latter product in particular having a higher content of sugars and metabolizable energy (ME) than the ' $\mathrm{C}$ ' (or final) molasses, is a potentially valuable substitute for cereal grains and their byproducts in diets for simple-stomached animals. Pigs are the major source of animal protein in Vietnam and it is important to improve the productivity and profitability of the village systems and to evaluate cereal substitutes for large scale production. Obvious alternatives to cereals include ' $\mathrm{A}$ ' and ' $\mathrm{C}$ ' molasses, which are already being utilized successfully in a number of Central and South American countries, and sugar cane juice, which can be easily produced from simple crushes on the farm. Ducks are also important sources of meat and eggs in Vietnam, particularly in the main irrigated rice growing areas, such as the Mekong Delta region, and sugar cane by-products can be an attractive alternative to the cereal component of their diet.

\section{Material and methods}

Experiment 1: ad-libitum ' $A$ ' molasses in diets for fattening pigs

Trial 1. A total of 16 Yorkshire castrated males and gilts (two replicates of four animals per treatment) of $30 \mathrm{~kg}$ initial live weight were given free access to either rice bran (control) or ' $A$ ' molasses, plus $200 \mathrm{~g}$ protein concentrate per pig per day through to slaughter after 18 weeks on experiment.

Trial 2. The design of the second trial was similar to that of trial 1 except that the intake of the protein concentrate was adjusted to give the same crude protein $(C P)$ intake for both treatments.

Experiment 2: optimum level of ' $A$ ' molasses in diets for growing pigs

A total of 20 F1 Yorkshire $X$ local breed crosses were allocated to one of four treatments, consisting of a basal ration (control) substituted by 200,250 or $300 \mathrm{~g} / \mathrm{kg}$ of ' $\mathrm{A}$ ' molasses on a dry matter (DM) basis. The basal diet and molasses were mixed with an equal weight of water and offered ad libitum to the pigs between 30 and $80 \mathrm{~kg}$ live weight.

Experiment 3: 'C' (final) molasses in dicts for growing pigs A total of 36 Vietnamese $\times$ Large White pigs were allocated to one of three diets, containing 0 (control), 260 (medium) or 460 (high) $\mathrm{g} / \mathrm{kg}$ ' $\mathrm{C}$ ' molasses on a DM basis. The molasses replaced a rice bran-based concentrate and a protein supplement, the proportions of which being adjusted to give the same mean daily $\mathrm{CP}$ intake of $275 \mathrm{~g}$ and ME intake of $27 \mathrm{MJ}$.

Experiment 4: use of sugar cane juice and ' $A$ ' molasses in diets for fattening ducks

A total of 270 Cherry Valley ducklings were allocated at 21 days of age to one of three dietary treatments, with three replicates of 30 birds per treatment. The control group were given a conventional dry diet based on broken rice, rice polishings, maize meal, fish meal and soya-bean meal. For treatment 2, cane juice replaced a mixture of the cereal components of the basal diet, with the level of juice being progressively increased from proportionately 0.3 of the DM of the diet at 28 days of age to a maximum of 0.7 at 42 days of age. Similarly on treatment 3 , ' $A$ ' molasses progressively replaced the rice and maize meal of the basal diet. Calculated concentrations of $\mathrm{CP}$ and $\mathrm{ME}$ were identical for all three treatments. The dry food, molasses and cane juice were mixed with water and offered ad libitum. The birds had access to fresh water for swimming each day. 


\section{Results}

Experiment 1

Trial 1. For the control and molasses-fed groups, daily DM food intakes were 1.96 and $1.65 \mathrm{~kg}$, daily weight gains 457 and $397 \mathrm{~g}(P>0.01)$, food conversion 4.28 and 4.14 and faeces moisture 623 and $847 \mathrm{~g} / \mathrm{kg}$, respectively. Cost of food per $\mathrm{kg}$ weight gain was proportionately about $\mathbf{0 . 2 5}$ higher for the molasses diet.

Trial 2. Mean daily DM intakes were 1.31 and $1.45 \mathrm{~kg}$, daily weight gains 549 and $524 \mathrm{~g}$, food conversion 3.25 and 4.14 and faeces moisture 702 and $756 \mathrm{~g} / \mathrm{kg}$ for the control and molasses-fed groups, respectively. Food cost per $\mathrm{kg}$ gain was around 0.26 higher for the molasses diet.

\section{Experiment 2}

For the $0,200,250$ and $300 \mathrm{~g} / \mathrm{kg}$ molasses diets average daily DM intakes were $2.22,2.38,2.46$ and $2.51 \mathrm{~kg}$; daily gains $529,518,522$ and $521 \mathrm{~g}(P>0.05)$; food conversion 4.19, 4.60, 4.72 and 4.81 and cost of food per $\mathrm{kg}$ gain equivalent to US $\$ 0.73,0.71,0.71$ and 0.70 , respectively.

\section{Experiment 3}

Between 30 and $90 \mathrm{~kg}$ live weight mean daily gains were 596, 569 and $576 \mathrm{~g}(P>0.05)$, and food conversion $4.19,4.31$ and 4.35 for the control, medium or high molasses diets, respectively.

\section{Experiment 4}

Daily gains up to slaughter at 60 days of age on the control, cane juice and molasses diets were $52.3,46.0$ and $38.6 \mathrm{~g}$, respectively $(P<0.05)$, mean daily DM intakes 142,161 and $156 \mathrm{~g}$, and food conversion 2.72 , 3.51 and $4.03(P<0.05)$, respectively. The livers of the cane juice and molasses-fed birds were heavier at slaughter, $43.3,53.2$ and $57.4 \mathrm{~g}$, respectively.

\section{Discussion}

' $A$ ' molasses can completely replace rice byproducts in finishing pig diets without significantly affecting performance, although it may not be profitable to feed it to pigs due to its high opportunity cost for alcohol manufacture. However prices fall considerably in the cane harvesting season when it can be significantly cheaper than rice bran. Final (' $C$ ') molasses has a lower ME content than ' $A$ ' molasses, but in the experiment reported here gave similar levels of performance to the control diet. As the price is usually around one-third of that of rice bran and ' $A$ ' molasses it would normally be profitable to include high levels in finishing pig diets.

Replacement of cereals in growing duck diets by cane juice depressed growth rates slightly, but as it can be easily and cheaply produced on the farm it can be an attractive alternative to rice bran. High levels of molasses in diets for ducks result in excreta with a high moisture content, which soils the feathers and stresses the birds unless they have access to fresh water for swimming. 